\title{
CAN NEGOTIATIONS WITH VIOLENT EXTREMISTS HELP PROMOTE JUSTICE FOR VICTIMS?
}

DOI: $10.20542 / 2307-1494-2020-2-216-219$

Transitional Justice and Violent Extremism. Barcelona: Institute for Integrated Transitions, 2020. 203 p.

The Institute for Integrated Transitions (IFIT) is an independent, nongovernmental organization located in Barcelona, Spain. Its aim is to foster integrated strategy and policymaking solutions for the transition of states affected by conflict or repression. The report on "Transitional justice and violent extremism" published in September 2020 is part of a research project on conflict resolution strategies with violent extremist groups that IFIT conducted in partnership with the United Nations University Centre for Policy Research. The report includes an original policy framework, written by international criminal and human rights law expert Ronald C. Slye, and three field-based case studies. The case studies include peace talks between the Ugandan government and the Lord's Resistance Army (LRA), negotiations between the regime of Muammar Gaddafi and the Libyan Islamic Fighting Group (LIFG) in Libya before 2011, and post-2001 conflict resolution and transitional justice efforts with the Taliban in Afghanistan. The authors are Barney Afako for the Uganda case study, Mary Fitzgerald and Emadeddin Badi for Libya and Orzala Nemat and Srinjoy Bose for Afghanistan. From a methodological standpoint, each case study is based on relevant literature, field-based reports and interviews with a diverse group of local, national, and international stakeholders.

The book underscores the problem that militaristic, punitive and often fragmented state actions against violent extremist groups fail to address structural causes of conflicts or to break cycles of grievances. It explains why negotiations maybe a useful option in engaging with some violent extremist groups and how innovative applications of transitional justice can make negotiated deals both more attainable and legitimate in the long term.

The book's overall analytical framework and case studies are centered around three crucial questions for conflict resolution and transitional justice strategies: the organizational structure of violent extremist groups, ways to initiate and engage in negotiations and, finally, strategies for transitional justice.

Organizational analysis of violent extremist groups. The book provides guidelines on how to evaluate whether and how violent extremist groups are willing to negotiate and accept transitional justice initiatives in a given context. The authors stress the importance of the constant fluidity of key aspects of such organizations. Significant factors to consider include the relationship between the group and the state (aligned, indifferent or confrontational). When addressing the structure and appeal of the group, policymakers should consider the group's ideological backdrop and its adherents' motivations for membership as well as its levels of bureaucratization and hierarchy. The Taliban, for instance, show complicated governance structure, with a leadership council and several political and military sub-bodies. The relationship of the group with the local community also needs to be examined. For instance, the complex relationship between the Acholi community in Northern Uganda and the LRA can be partially explained by the forcible recruitment of children by the LRA. Thus, even if the local community is victimized by extreme violence, it may continue to perceive members as victims as much as perpetrators and to be reluctant to oppose them.

Key sequencing of engagement and negotiation. When it comes to the entry into, and the process of, negotiations, the authors advise that preference should be given to 
incremental, confidence-building measures over hasty procedures. In this sense, understanding the circumstances of a group's formation and its ongoing incentives may indicate issues that can promote negotiations, such as tackling real and perceived grievances that the organization seeks to address. For example, Betty Bigombe's use of local knowledge and empathy towards the LRA's spiritual beliefs helped advance the 1992-1994 negotiations between the LRA and the Uganda government towards a ceasefire. This approach also provides insight for effective methods of communication. The usage of the Islamic language and the Islamic framework was important to the successful dialogue between the LIFG and the Gaddafi government. Also, as the key mediator in the LIFG dialogue process Ali Sallabi was an Islamic scholar who had himself been an Abu Salim prisoner, he was able to establish a relationship of confidence with imprisoned LIFG leaders. A successful communication strategy should also focus on other stakeholders, such as victims and the public.

Transitional justice strategies. According to the report, criminal prosecution can be an important strategy for transitional justice, even though rigid legalistic approaches have often failed in countering extremist violence. As victims may demand prosecution of perpetrators for their crimes, a credible threat of prosecution may encourage participation in negotiations in exchange for leniency. Furthermore, the presence of the International Criminal Court can be used as an additional source of pressure to push for concessions, at least for perpetrators of the most severe atrocities. However, it also adds another level of complexity to the negotiating environment. Considering this, the authors argue that any accountability strategy also needs to include victims and the public. In the Afghanistan and Uganda case studies, the use of customary or local trials (rawaj for Afghanistan and mato oput for Uganda) applied local expertise and gave "agency" to victimized communities.

Another issue, or option, to consider are amnesties or other forms of legal leniency. Often viewed as equivalents of impunity, they can make solid starting points for negotiations. However, as the Afghanistan case study shows, if such measures are viewed as one-sided, they risk weakening the legitimacy and effect of other conflict resolution measures.

One of the book's main arguments is that a holistic approach is needed for conflict resolution. In other words, the strategy suggested by the authors implies a process of mapping out the key stakeholders (violent extremist groups, governments, the public, victims) and analyzing how a set of available actions relates them to each other (negotiations, government's communication with armed groups and the public, inclusion of victims in prosecution and accountability processes etc.).

Even as the IFIT's analysis addresses a range of actors, it remains firmly within a state-centered approach. Strategies and approaches it offers are largely articulated for governments of states where structural causes for violent extremism and operational endeavors of militant groups are concentrated. However, the close interaction between states and international and transnational actors necessitates a more comprehensive approach to conflict resolution and institutional reform efforts, transcending state boundaries. Clara Sandoval argues that a diverse set of actors need to participate visibly in negotiations and (especially) transitional justice, such as "regional human rights courts (as opposed to criminal tribunals), local or traditional courts, international cooperation agencies, non-governmental organizations and transnational corporations". ${ }^{1}$ In order to go beyond top-down, state-based interventions, Gready and Robins introduce the idea of "transformative justice" that emphasizes agency and resources of local communities and prioritizes the transition process rather than fixed outcomes. ${ }^{2}$ Resolution of conflicts that involve violent extremist groups should therefore be considered vis-à-vis more general peacebuilding and development measures, to ensure appropriate allocation of (often scarce) human and economic resources. 
Moreover, the IFIT report stresses the "importance of victim-sensitive mindset to create public support" for conflict resolution efforts. ${ }^{3}$ Unless victims are included in both negotiations and truth commissions or reparation efforts, the punishment of perpetrators could be perceived as political retaliation. This line of thinking corresponds to the 2016 UN "Report of the Special Rapporteur on the Promotion of Truth, Justice, Reparation and Guarantees of Non-Recurrence" that gives both an epistemic argument ("victims contribute to quantity and quality of information") and a legitimacy-based argument ("participation gives victims recognition as rights holders and presence in public discourse") for victim inclusion. ${ }^{4}$

The final aspect of conflict resolution considered in the IFIT publication (especially in the case study of LRA) is its gender dimension and treatment of disenfranchised members of society, especially children. According to the International Centre for Transitional Justice, the crime of illegal recruitment of children committed by some militant groups is often not fully understood by communities and raises the issue of restorative vs. retributive justice for atrocities perpetrated by child members of violent extremist groups. ${ }^{5}$

In sum, the difficulty of engaging in negotiations and transitional justice efforts with violent extremist groups can be explained by their usage of extreme violence, their transnational reach and appeal to populations disaffected with state structures. In three case studies discussed in the book, only negotiations between the Gaddafi government and LIFG resulted in the dissolution of the violent extremist group (while the LIFG's highest in command had already been imprisoned during negotiations). The authors' important contribution to policy and strategy efforts is their understanding of and emphasis on the fluidity of organizations' structures and motivations. As the book rightfully points out, motivations, capacities, and aims of violent extremist groups may change over time, at times rapidly. Any conflict resolution strategy must therefore rely on real-time analysis and be continuously reassessed, updated and adapted.

While acknowledging that circumstances and variables for conflict resolution are ever-changing, the publication provides a framework for analyzing a diverse set of situations and fostering good practices in negotiations with armed groups and transitional justice. In this sense, the checklists provided at the end of chapters' policy framework sections are particularly useful as guidelines for policymakers.

Finally, in a world where many governments nominally "refuse to negotiate with violent extremists" and engage in misleadingly reductionist public discourse about such groups and their supporters, this IFIT report offers a refreshing and valuable contribution to the literature on conflict resolution and transitional justice. It asserts that negotiations (when combined with coercion) can be a useful approach to reduce violence in the short run. Moreover, in the long run, this approach allows to weaken a group's appeal, provide support to its victims, and avoid the recurrence of similar threats. The fact that these policy recommendations are concluded on the basis of close examination of three separate case studies, relying on first-hand experience and interviews with a variety of stakeholders, lends further credence to the policy and strategy solutions put forward.

Emilie Berger* Institut d'études politiques de Paris

(Sciences Po)

\footnotetext{
* Emilie Berger (Austria) is an exchange student from Institut d'études politiques de Paris (Sciences Po) at MGIMO-University, Moscow.

Эмили Бергер (Австрия) - участница программы образовательного обмена из Института политических исследований, Франция, в МГИМО-Университете.
} 


\section{ENDNOTES}

${ }^{1}$ Sandoval C. Transitional Justice: Key Concepts, Processes and Challenges. - Colchester: Institute for Democracy and Conflict Resolution, 2011. P. 11.

2 Gready P., Robins S. From transitional to transformative justice: a new agenda for practice // The International Journal of Transitional Justice. V. 8. № 3. 2014. P. 339-361.

${ }^{3}$ Slye R.C., Afako B., Fitzgerald M., Badi E., Nemat O., Bose S. Transitional Justice and Violent Extremism. Barcelona: IFIT, 2020. P. 14.

${ }^{4}$ De Greiff P. Report of the Special Rapporteur on the Promotion of Truth, Justice, Reparation and Guarantees of Non-Recurrence. Note by the Secretariat. UN Human Rights Council. UN Doc. A/HRC/34/62, 2016.

${ }^{5}$ Aptel C., Ladisch V. Through A New Lens: A Child-Sensitive Approach to Transitional Justice. - New York; Brussels: International Center for Transitional Justice, 2011.

\section{BIBLIOGRAPHY}

1. Aptel C., Ladisch V. Through A New Lens: A Child-Sensitive Approach to Transitional Justice. New York; Brussels: International Center for Transitional Justice, 2011. URL: https://www.ictj.org/ sites/default/files/ICTJ-Children-Through-New-Lens-Aptel-Ladisch-2011-English.pdf.

2. De Greiff P. Report of the Special Rapporteur on the Promotion of Truth, Justice, Reparation and Guarantees of Non-Recurrence. Note by the Secretariat. UN Human Rights Council. UN Doc. A/HRC/34/62, 2016. URL: https://digitallibrary.un.org/record/861415?ln=en.

3. Gready P., Robins S. From transitional to transformative justice: a new agenda for practice // The International Journal of Transitional Justice. V. 8. № 3. 2014. P. 339-361. DOI:10.1093/ijt/iju013. URL: https://www.york.ac.uk/media/cahr/documents/IJTJ-2014-Gready-339-61.pdf.

4. Sandoval C. Transitional Justice: Key Concepts, Processes and Challenges. Institute for Democracy and Conflict Resolution (IDCR) Briefing Paper, University of Essex. - Colchester: IDCR, 2011. URL: http://repository.essex.ac.uk/4482/1/07_11.pdf.

5. Slye R.C., Afako B., Fitzgerald M., Badi E., Nemat O., Bose S. Transitional Justice and Violent Extremism. - Barcelona: Institute for Integrated Transitions (IFIT), 2020.

URL: https://www.ifittransitions.org/publications/major-publications-briefings/transitional-justiceand-violentextremism/collated-report-transitional-justice-and-violent-extremism-1.pdf/view 